Provided for non-commercial research and education use. Not for reproduction, distribution or commercial use.

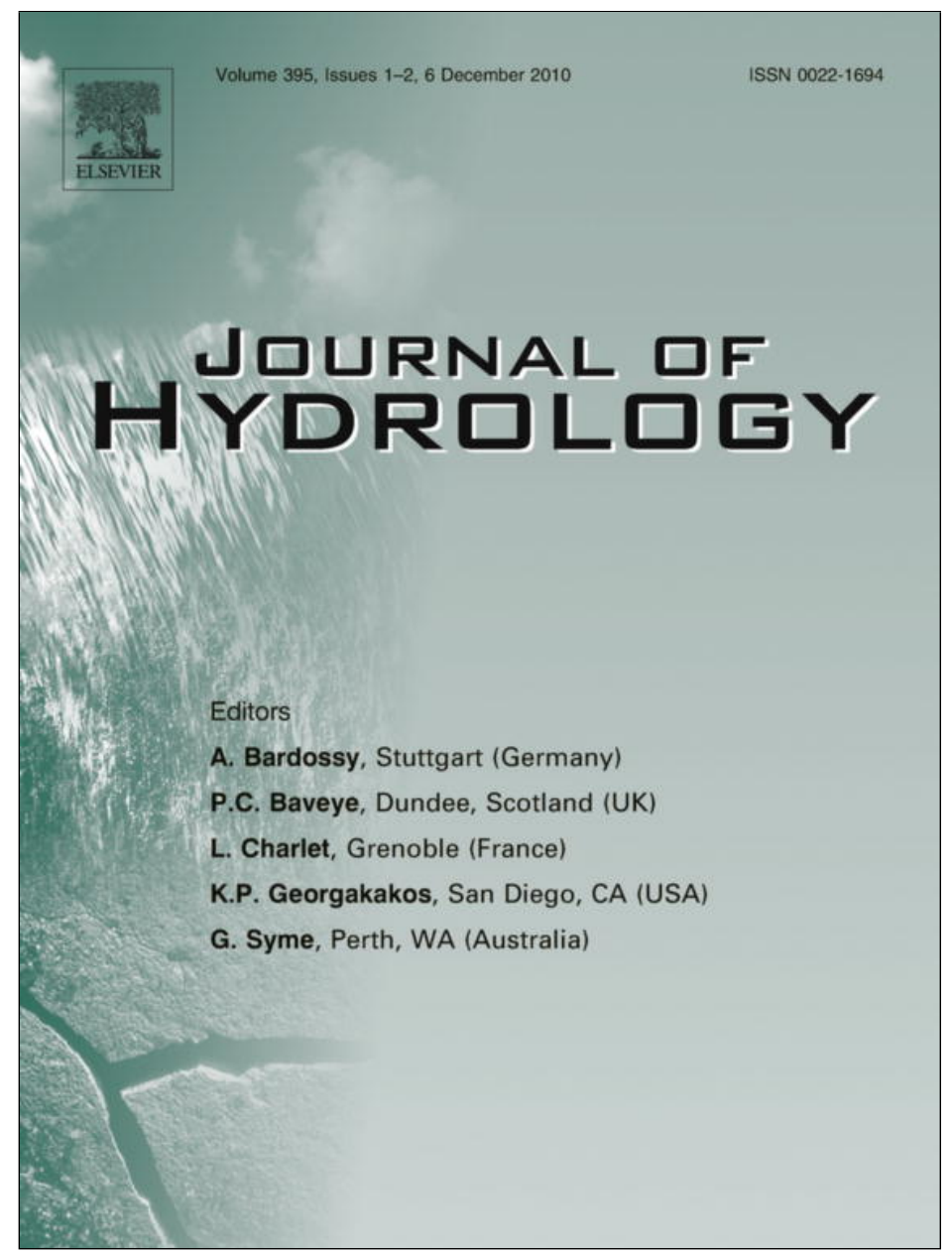

This article appeared in a journal published by Elsevier. The attached copy is furnished to the author for internal non-commercial research and education use, including for instruction at the authors institution and sharing with colleagues.

Other uses, including reproduction and distribution, or selling or licensing copies, or posting to personal, institutional or third party websites are prohibited.

In most cases authors are permitted to post their version of the article (e.g. in Word or Tex form) to their personal website or institutional repository. Authors requiring further information regarding Elsevier's archiving and manuscript policies are encouraged to visit:

http://www.elsevier.com/copyright 


\title{
Rainfall partitioning into throughfall, stemflow and interception loss in a coffee (Coffea arabica L.) monoculture compared to an agroforestry system with Inga densiflora
}

\author{
Pablo Siles $^{\mathrm{a}, 1}$, Philippe Vaast ${ }^{\mathrm{b}}$, Erwin Dreyer ${ }^{\mathrm{c}, \mathrm{d}}$, Jean-Michel Harmand ${ }^{\mathrm{b}, *}$ \\ ${ }^{a}$ CATIE (Centro Agronómico Tropical de Investigación y Enseñensa), Turrialba 7170, Costa Rica \\ ${ }^{\mathrm{b}}$ CIRAD (Centre de Coopération Internationale en Recherche Agronomique pour le Développement), UPR80 “Ecosystèmes de Plantations”, s/c UMR EcoछSols, 2 Place Viala, \\ Bât 12, 34060 Montpellier Cedex 01, France \\ "INRA (Institut National de la Recherche Agronomique), UMR1137 “Ecologie et Ecophysiologie Forestières", 54280 Champenoux, France \\ d Nancy-Université, UMR1137 "Ecologie et Ecophysiologie Forestières", 54500 Vandoeuvre, France
}

\section{A R T I C L E I N F O}

\section{Article history:}

Received 31 January 2009

Received in revised form 17 July 2010

Accepted 6 October 2010

This manuscript was handled by L. Charlet, Editor-in-Chief, with the assistance of Prosun Bhattacharya, Associate Editor

\section{Keywords:}

Evaporation

Humid tropics

Multi-strata system

Funneling ratio

Water cycle

\begin{abstract}
S U M M A R Y
Partitioning of gross rainfall into throughfall, stemflow and rainfall interception was assessed in Costa Rica during two rainy seasons (mean annual rainfall of $2900 \mathrm{~mm}$ ) in two coffee systems: (1) a monoculture (MC) and (2) an agroforestry system (AFS) including Inga densiflora as the associated shade tree species. Coffee architecture, not LAI, appeared to be the main driver of stemflow as stemflow was higher for shaded coffee plants (10.6\% of incident rainfall) than for coffee plants in MC (7.2\%), despite the fact that these shaded plants had lower LAI. The presence of Inga trees modified coffee architecture with shaded coffee plants presenting larger stems and branches resulting in higher coffee funneling ratio under shade. In AFS, coffee plants and trees accounted respectively for $88 \%$ and $12 \%$ of total stemflow which represented $11.8 \%$ of incident rainfall. AFS displayed larger cumulative stemflow and smaller total throughfall compared to MC. Cumulative throughfall expressed in \% of the gross rainfall, differed between systems and monitoring periods and the trend showed a decrease with increasing LAI. Nevertheless, as stemflow measurement and interception loss estimation were done only during the second year of the study, the shade tree showed a low influence in increasing interception loss, as the combined LAI of coffee plants and shade trees was rather similar in AFS as that of coffee in MC. Furthermore, coffee plants accounted for the largest fraction of the interception loss in AFS as the coffee LAI was more than 3-fold that of shade trees.
\end{abstract}

(C) 2010 Elsevier B.V. All rights reserved.

\section{Introduction}

Coffee (Coffea arabica L.) is one of the major sources of foreign exchange in Central America where it is cultivated under various management schemes from heavy shade to full sun, distinct climate conditions, and varying intensification regimes according to farmers' constraints and needs in a highly fluctuating market context (Varangis et al., 2003). Coffee, cultivated under shade trees in agroforestry systems (AFS), may provide economical and environmental benefits with respect to coffee grown in monoculture (MC) for the following reasons: (1) by modifying the micro-environment, shade trees reduce coffee stress and flowering intensity, and hence overbearing and dieback of coffee plants while improving coffee quality; (2) leguminous trees enhance soil fertility

\footnotetext{
* Corresponding author. Tel.: +33 (0)4 996121 68; fax: +33 (0)4 99612119 .

E-mail address: jean-michel.harmand@cirad.fr (J.-M. Harmand).

1 Present address: Bioversity, Catie, Turrialba 7170, Costa Rica.
}

through nitrogen fixation, soil organic matter accumulation and increased nutrient cycling; and (3) trees also reduce runoff and enhance soil infiltration capacity through an improved surface status and an increased root density (Fournier, 1988; Beer et al., 1998; Vaast et al., 2007; Siles et al., 2010).

Generally, the presence of shade trees may influence the hydrological cycle by affecting rainfall distribution and interception, runoff, infiltration and evapo-transpiration in coffee plantation. Two studies have been undertaken in Mexico and Costa Rica on water consumption in coffee MC or in coffee AFS (Jiménez and Goldberg, 1992; van Kanten and Vaast, 2006). They showed that (1) coffee transpiration by unit leaf area decreased with increasing shade level and (2) combined water consumption of coffee and shade tree was higher than that of coffee in MC. However, less information is available on the effects of trees on the other components of the hydrological cycle, particularly on rainfall interception loss by coffee and tree canopies. Rainfall partitioning into throughfall, stemflow and interception loss by plant canopies determines the 
amount and the spatial distribution of water reaching the soil. Preferential water pathways such as plant stem (stemflow) and juxtaposition of dripping and protected areas in the canopy lead to spatial variability in water fluxes. Hence, this redistribution of rainfall by plant canopy may affect runoff and infiltration (Cattan et al., 2007a,b) as well as the soil water content and distribution in addition to plant specific transpiration. Spatial and time scales and variability of water fluxes remain important issues which can be addressed through modeling. Therefore, the data set analysis reported here on rainfall distribution between throughfall, stemflow and canopy interception loss in two coffee systems should be useful for future model developments.

Canopy interception loss depends greatly on the properties of the canopy, such as vegetation storage capacity (foliage area and stem water storage capacity), multi-layer nature of the canopy, evaporation during rainfall, as well as rainfall amount and frequency (Huber and Iroumé, 2001; Hall, 2003). Most studies on interception loss have been carried out in temperate and tropical forests; little information is available in the literature regarding tropical, perennial agricultural systems and most of these studies referred only to throughfall for examples in cocoa (Jaramillo, 2003) or coffee (Imbach et al., 1989; Harmand et al., 2007).

Generally, stemflow in tropical forests (Tobon Marin et al., 2000; Hölsher et al., 2004) or in cocoa plantation (Levia and Frost, 2003 ) represents $1-2 \%$ of rainfall and is often ignored in the water budget. Nevertheless, in some tropical agricultural systems such as banana plantain, relatively high stemflow rates (9-10\% of incident rainfall) were found by Jimenez and Lhomme (1994) and even higher ones $(18-26 \%$ of the incident rainfall) were recorded by Cattan et al. (2007a) in an industrial banana plantation. No information was found in the literature with respect to stemflow evaluation in coffee plantation.

The introduction of trees into coffee plantations is expected to reduce the net rainfall input to the soil by increasing canopy interception loss as well as to decrease runoff by increasing the soil infiltration capacity. The present study was designed to address this former issue by measuring rainfall partitioning between throughfall, stemflow and interception in two contrasting coffee systems. One MC and one AFS with Inga densiflora were monitored during two successive years in the main coffee production area of Costa Rica although stemflow was only measured during one rainy season. In the present article, the structure of these two coffee systems, rainfall, throughfall and stemflow measurements are presented. Interception loss, calculated from the previous water fluxes, is also presented and discussed.

\section{Materials and methods}

\subsection{Site description and experimental design}

The study was conducted on the research station of the Coffee Institute of Costa Rica (Icafé), located in San Pedro de Barva in the Central Valley of Costa Rica $\left(10^{\circ} 02^{\prime} 16^{\prime \prime} \mathrm{N}, 84^{\circ} 08^{\prime} 17^{\prime \prime} \mathrm{O} ; 1200 \mathrm{~m}\right.$ above sea level). The mean annual temperature was about $21^{\circ} \mathrm{C}$ and annual precipitation was about $2300 \mathrm{~mm}$ with a pronounced dry season from January to April. The soil, derived from the weathering of volcanic ashes, belongs to Andisols and is classified as a Dystric Haplustands (Mata and Ramirez, 1999).

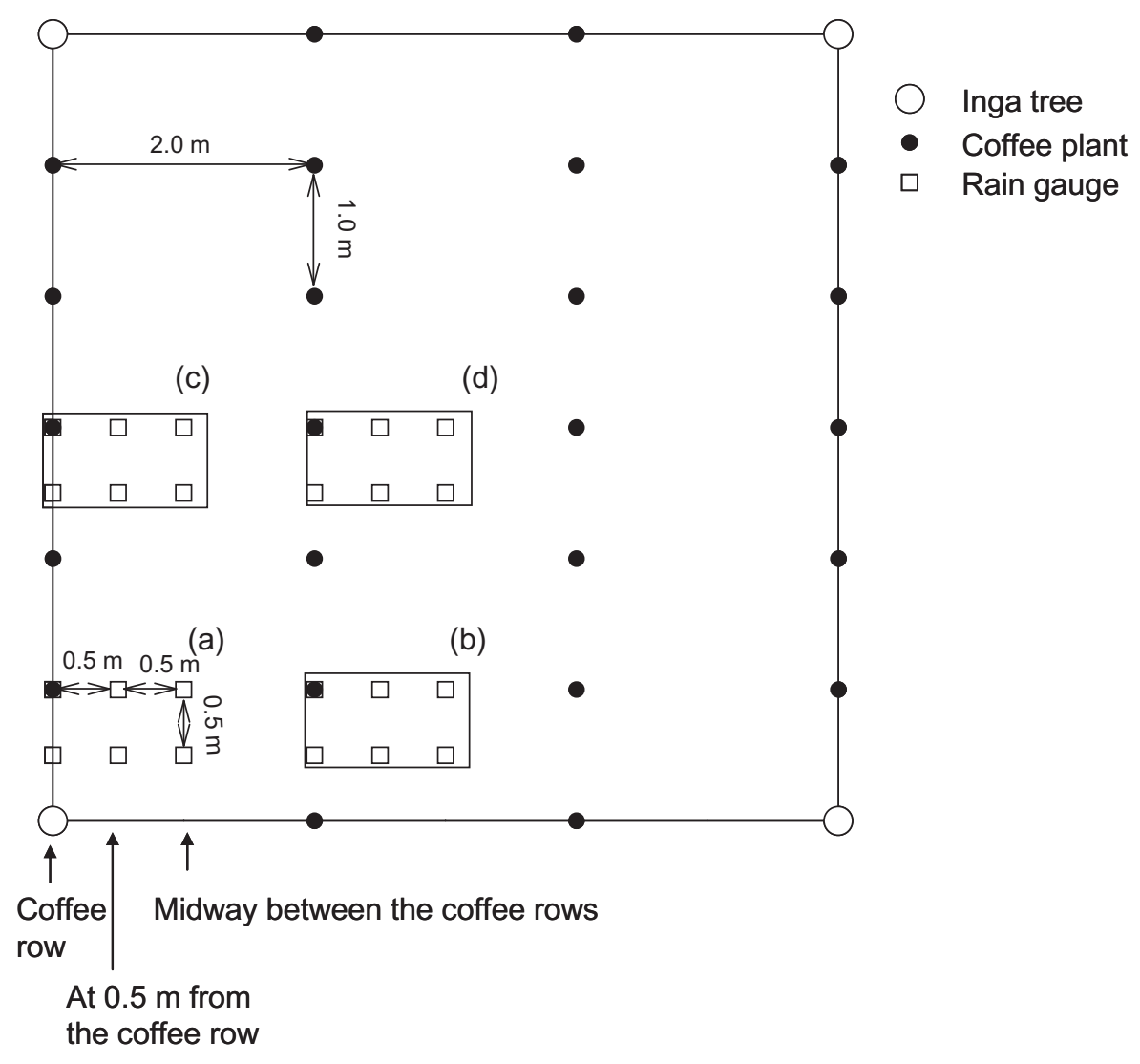

Fig. 1. Schematic representation of the layout of four sets of six rain gauges for measuring throughfall in the coffee agroforestry system with respect to distances to coffee plants and shade trees (Inga densiflora) at the research site in the Central Valley of Costa Rica. The four sets of six rain gauges were located at (a) 0.5-1.4 m, (b) 2.1-3.1 m, (c) 2.5-3.1 m and (d) 3.2-4.2 m from the closest Inga tree. This layout located inside a quadrate formed by four shade trees was repeated three times for a total of 12 sets of six rain gauges. 
The experimental design included two adjacent coffee plots: a shaded one (AFS, $1520 \mathrm{~m}^{2}=40 * 38 \mathrm{~m}$ ) and a second one without trees (MC, $1200 \mathrm{~m}^{2}=40 * 30 \mathrm{~m}$ ). The two plots were in a large open field area with uniform topography and gentle slope $(<5 \%)$. The distance between these two plots was $33 \mathrm{~m}$ (i.e. at least four times the Inga tree height), thus limiting greatly the potential border effect between treatments. In both plots, coffee (Coffea arabica L., variety "Caturra") was planted in 1997, following a coffee monoculture, with a spacing of $2 \mathrm{~m}$ between rows and $1 \mathrm{~m}$ within the rows, which resulted in 5000 and 4722 coffee plants ha ${ }^{-1}$ for the MC and AFS, respectively. On average, three coffee plants were placed in each planting hole. In AFS, Inga densiflora (Benth) was planted within the coffee rows at a spacing of $6 \times 6 \mathrm{~m}$ ( 278 trees ha ${ }^{-1}$ ) as shown in Fig. 1 . The plots were equally intensively managed with an annual fertilization of $250 \mathrm{~kg} \mathrm{~N} \mathrm{ha}^{-1}$, $30 \mathrm{~kg} \mathrm{P} \mathrm{ha}^{-1}$ (triple superphosphate), $100 \mathrm{~kg} \mathrm{~K} \mathrm{ha}^{-1}(\mathrm{KCl}), 80 \mathrm{~kg} \mathrm{Mg}$

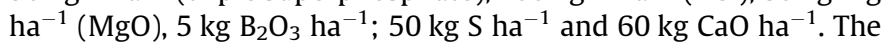
structure of the two systems and throughfall were recorded during the main part of the rainy season, June to September in 2004 and July to November in 2005. Tree and coffee stemflow was also measured during the monitoring period of 2005.

\subsection{Canopy structure}

In AFS, the architecture of the shade tree species consisted in a short trunk ramifying into two to three vertical stems at a mean height of $75 \mathrm{~cm}$. Therefore, diameter at breast (i.e. $1.30 \mathrm{~m}$ ) height (DBH) of all stems, generally two to three per tree, for all individual shade trees (41 trees) was measured in July 2004 and August 2005 to estimate tree basal area (i.e. total of tree stem area at $1.30 \mathrm{~m}$ height on a per ha basis in $\mathrm{m}^{2} \mathrm{ha}^{-1}=\sum\left(\mathrm{DBH}(\mathrm{m})^{2} *\right.$ pi/4)/area of the plot $\left.\left(\mathrm{m}^{2}\right) * 10,000\right)$. Simultaneously, tree biomass was recorded via an allometric relationship established between DBH and biomass of individual vertical sub-stems of 11 trees (Siles et al., 2010). Before and after felling down these trees, hemispherical photographs were taken below their canopy, analyzed with the Gap Light Analyzer (GLA) software (Frazer et al., 1999) and the estimated LAI of individual trees were related to the actual LAI of felled trees measured by scanning all the leaves of each tree with an image-scanning program (Whinrhizo, V.3.9, Regent Instruments). Subsequently, 100 hemispherical photographs were taken during July 2004 and August 2005, above the coffee canopy to estimate tree canopy openness and LAI of the tree layer at the plot level.

In both systems, coffee basal diameter of stems (at $10 \mathrm{~cm}$ above soil surface) was recorded during July 2004 and August 2005 on 156 plants in a sub-plot area of $312 \mathrm{~m}^{2}$. Eight coffee plants, with basal diameter representative of the population in each sub-plot, were selected to measure leaf area and estimate LAI according to the following method. The leaf area of these eight coffee plants per system was measured to estimate coffee LAI in February 2004, September 2004, February 2005, April 2005, June 2005 and October 2005. In February 2004, it consisted in the scanning of all the individual leaves of each plant with an image-scanning program (Whinrhizo, V.3.9, Regent Instruments) to determine precisely their respective leaf area as well as the measurements of their length and the width; an estimation for the individual leaf area (leaf area $=0.69 \mathrm{LW}$ ) was determined as the product of leaf length $(L)$ and width $(W)$ by correlation with the precise leaf area derived from the scanning process $\left(R^{2}=0.96\right)$. Due to the fact that (1) these measurements were labour intensive and time-consuming, (2) coffee leaf lifespan was about 8-12 months, and (3) new leaves were produced regularly at the rate of one pair per month during 10 months a year resulting in a constant leaf size distribution over the year, a simplification was developed to estimate coffee LAI for the subsequent dates. It consisted in counting all the leaves of a coffee plant and multiplying this total leaf number by the average leaf area derived from measurements undertaken in February 2004. Biomass measurements were carried out on eight coffee plants in July 2004 and August 2005 with stems, branches and leaves of each plant weighed separately.

Canopy storage capacity was estimated as the product of LAI and the mean water storage capacity of leaves of both species. The latter was estimated from seven groups of leaves with an average leaf area of $1200 \mathrm{~cm}^{2}$ for each species (30-40 leaves per group in the case of coffee plants). This mean water storage capacity of leaves was estimated as the difference between the weight of freshly cut leaves and the weight of wet leaves immersed in water for $5 \mathrm{~min}$ and allowed to drip for $1 \mathrm{~min}$.

\subsection{Microclimate}

An automatic weather station was installed in an open field area next to the experimental plots. Relative humidity (RH\%) and air temperature (Temp, ${ }^{\circ} \mathrm{C}$ ) were measured by sensors (HMP45C, Campbell Scientific Corp., Logan, UT) at a height of $2 \mathrm{~m}$. Photosynthetic photon flux density (PPFD) was measured with quantum sensors (SOLEMS PAR-CBE 80, Palaiseau, France) and wind speed with an anemometer (Model 05103-5 Wind-monitor) at a height of $2 \mathrm{~m}$. Values were automatically recorded to a datalogger (CR10X Campbell Scientific Instruments). Two manual standard rain gauges were installed in the open next to the experimental plots and monitored daily in the morning. The two rain gauges provided rather similar values and the average of both values was taken as the reference daily gross rainfall (annual difference of about $40 \mathrm{~mm}$ between the two rain gauges, i.e. $1.5 \%$ of total annual rainfall). A tipping bucket gauge (Model ARG 100) which presented repeated calibration defects, provided information on duration of daily rainfall reliable enough to be taken into consideration. Reference evapo-transpiration (ETo in $\mathrm{mm} \mathrm{d}^{-1}$ ) was estimated with the FAO Penman-Monteith equation (Allen et al., 1998) with inputs (wind speed, Temp, RH and solar radiation estimated from PPFD values) from the meteorological station in the open.

\subsection{Throughfall}

Throughfall was monitored below coffee plants in both systems from June to September in 2004 and from July to November in 2005 with home made rain gauges consisting of plastic bottles (height of $25 \mathrm{~cm}$ and sampling area of $82 \mathrm{~cm}^{2}$ ) that were placed at ground level. In each system, 72 rain gauges were distributed into 12 sets, each composed of six rain gauges located at various distances from a coffee stem, to take into account the heterogeneity of coffee canopies. As shown on Fig. 1, in each set, two rain gauges were placed on the coffee row at $0.1 \mathrm{~m}$ and $0.5 \mathrm{~m}$ from the coffee plant, two gauges at $0.5 \mathrm{~m}$ from the coffee row and two gauges at $1.0 \mathrm{~m}$ from the coffee row at midway between the coffee rows. At the same time, according to the design shown in Fig. 1, sets of rain gauges were located at each of the four following distances (a) $1.0 \mathrm{~m}$; (b) $2.2 \mathrm{~m}$; (c) $3.0 \mathrm{~m}$ and (d) $3.6 \mathrm{~m}$ from a I. densiflora tree in three replicates, to take into account the natural variability in throughfall generated by the shade tree canopy. In MC, 12 sets of six rain gauges were placed at $4 \mathrm{~m}-8 \mathrm{~m}$ apart in a rectangular systematic design. No rain gauges were placed above the coffee plants to measure interception solely due to Inga trees.

\subsection{Stemflow of Inga densiflora}

Stemflow of shade trees (I. densiflora) was measured from July to November 2005 on six randomly chosen trees using collars constructed with $25 \mathrm{~mm}$ thick polyethylene plastic tubes that were slit opened and then sealed to each sub-stem of the tree (see Section 2.2) in an upward spiral. Water collected by the 
collar was diverted by a flexible tubing into a bucket placed on the ground floor. The stemflow volume of each tree was measured after every daily rain event. To estimate daily stemflow of trees $\left(\mathrm{mm} \mathrm{d}^{-1}\right)$, mean stemflow volume per tree and per day $(L)$ was multiplied by the tree density (278 stems ha ${ }^{-1}$ ) and divided by $10,000 \mathrm{~m}^{2}$.

\subsection{Stemflow of coffee plants}

Coffee stemflow was measured from July to November 2005 on 12 randomly chosen plants in each coffee system. Each coffee plant had an average of three stems. The coffee stemflow device consisted in a collecting cup sealed around each stem. Water collected in each cup was diverted by a flexible tubing to a bucket placed on the ground floor. To estimate daily coffee stemflow $\left(\mathrm{mm} \mathrm{d}^{-1}\right)$, the mean stemflow volume per plant and per day $(L)$ was multiplied by the respective coffee plant density of the two systems and divided by $10,000 \mathrm{~m}^{2}$. For daily rainfall above $40 \mathrm{~mm}$, the stemflow volume generally surpassed the capacity of the collectors. Therefore, above this threshold, the stemflow was estimated using the linear and highly significant $(p<0.0001)$ relationship developed between coffee stemflow and daily rainfall in the range of 10 $40 \mathrm{~mm}$. This assumption was done on rainfall events accounting for $25 \%$ of cumulative rainfall in 2005 .

\subsection{Funneling ratio of coffee plants and shade trees}

The funneling ratios (FR) of coffee and I. densiflora were computed for the monitoring period of July to November 2005 according to the following equation: $\mathrm{FR}=V / B G$, where $V$ is the stemflow volume in $L, B$ is the stem basal area in $\mathrm{dm}^{2}, G$ is the depth equivalent of incident gross precipitation in $\mathrm{dm}$.

\subsection{Canopy interception loss}

For each rainfall event, canopy interception loss was calculated in both systems as the difference between the registered gross rainfall in the open and the measured throughfall plus stemflow.

\subsection{Data analysis}

Statistical analyses were performed using various Statistical Analysis System (SAS/STAT, 2004) procedures. One way analyses of variance (ANOVA) were performed for LAI, canopy openness and biomass components to compare differences between coffee systems and years.

A two way analysis of variance was carried out to evaluate the effect of coffee canopy on the distribution of throughfall. Additionally for AFS, an ANOVA was performed to assess shade tree effect on spatial variability of cumulative throughfall with respect to the distance of the rain gauges to these shade trees. Rain gauge positions with respect to coffee rows and inter-rows were taken into account to estimate the total throughfall at the plot scale.

Regressions of throughfall versus gross rainfall as well as stemflow versus gross rainfall were developed with statistical significance assessed by a $t$-test. A test of homogeneity of variance was done before testing the statistical differences in the slopes and intercepts of the regression equations generated for the two systems. Additionally, an ANOVA was performed on the cumulative data of coffee stemflow to test differences between MC and AFS. Hyperbolic equations were fitted to describe the relationships between canopy interception loss and gross rainfall in each system and the statistical significance of the regression coefficients was also assessed by a $t$-test.

\section{Results}

\subsection{Tree and coffee structure and growth (Table 1)}

At the ages of 7 (July 2004) and 8 years (August 2005), trees (I. densiflora) had a mean DBH of $12.3 \mathrm{~cm} \quad(\min =7.5 \mathrm{~cm}$, $\max =17.2 \mathrm{~cm})$ and $13.5 \mathrm{~cm}(\min =9.3 \mathrm{~cm}, \max =18.2 \mathrm{~cm})$ and total basal areas (at $1.30 \mathrm{~m}$ height) of 8.36 and $8.51 \mathrm{~m}^{2} \mathrm{ha}^{-1}$, respectively. Coffee total basal area (at $10 \mathrm{~cm}$ height) was higher in MC than in AFS during the two consecutive years, due to larger stem diameter and a slightly higher density in MC than in AFS.

Despite larger tree basal area and tree stem biomass in 2005 than in 2004, a lower tree leaf biomass, lower tree LAI and higher tree canopy openness were recorded in 2005 than in 2004. This was due to the pruning of lower branches during October 2004.

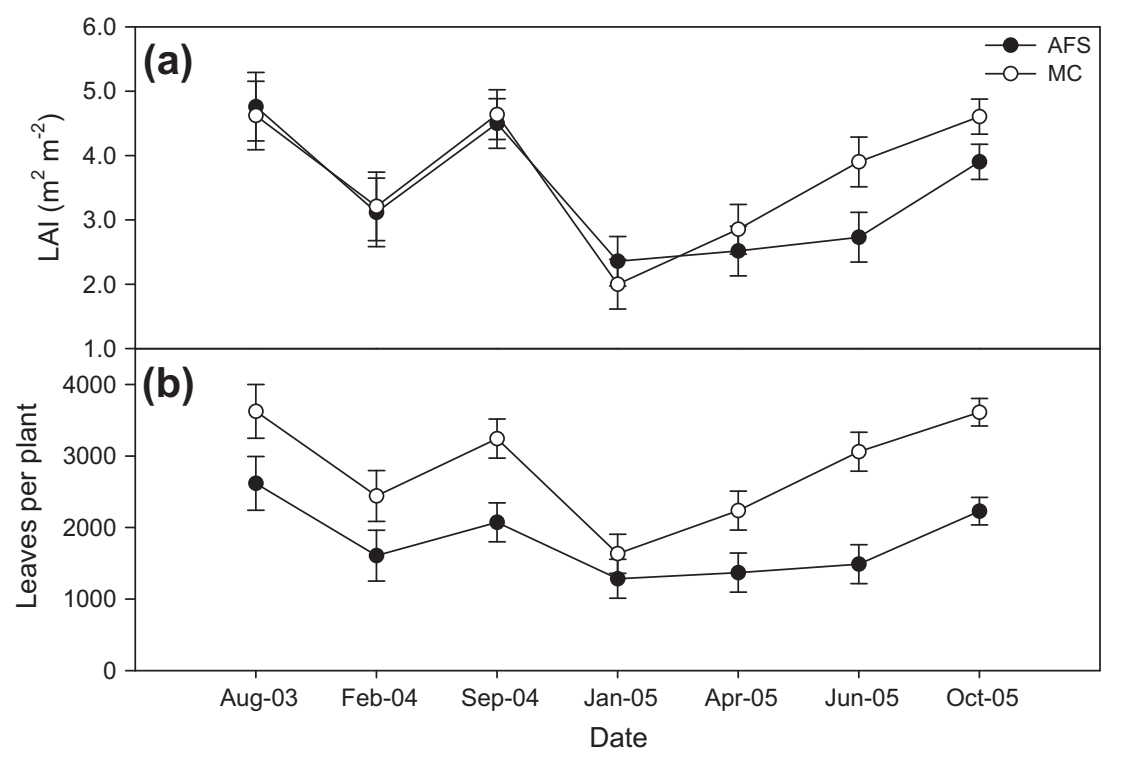

Fig. 2. Leaf area index (a) and number of leaves per plant (b) of coffee plants in monoculture (MC) and in an agroforestry system (AFS) in the Central Valley of Costa Rica (Mean \pm standard error). 
Table 1

Main characteristics of the two coffee systems (MC: monoculture and AFS: agroforestry system with Inga densiflora) at San Pedro de Barva in the Central Valley of Costa Rica in 2004 and 2005 (Mean \pm standard error).

\begin{tabular}{|c|c|c|c|c|c|c|}
\hline \multirow[t]{3}{*}{ Parameter } & \multicolumn{4}{|c|}{ AFS plot $\left(1520 \mathrm{~m}^{2}\right)$} & \multirow{2}{*}{\multicolumn{2}{|c|}{$\begin{array}{l}\text { MC }\left(1400 \mathrm{~m}^{2}\right) \\
\text { Coffee }\end{array}$}} \\
\hline & \multicolumn{2}{|l|}{ I. densiflora } & \multicolumn{2}{|l|}{ Coffee } & & \\
\hline & 2004 & 2005 & 2004 & 2005 & 2004 & 2005 \\
\hline Density (plant ha ${ }^{-1}$ ) & 278 & 278 & 4722 & 4722 & 5000 & 5000 \\
\hline Canopy openness (\%) & $30.2 \pm 0.6$ & $32.8 \pm 0.7$ & & & & \\
\hline $\operatorname{LAI}\left(\mathrm{m}^{2} \mathrm{~m}^{-2}\right)$ & $1.32 \pm 0.03$ & $1.22 \pm 0.03$ & $4.64 \pm 0.38 a^{A, B}$ & $3.80+0.22 \mathrm{~b}^{\mathrm{A}, \mathrm{B}}$ & $4.71 \pm 0.39 \mathrm{a}^{\mathrm{A}, \mathrm{B}}$ & $4.60 \pm 0.27 \mathrm{a}^{\mathrm{A}, \mathrm{B}}$ \\
\hline Canopy storage capacity ${ }^{\mathrm{d}}(\mathrm{mm})$ & $0.18 \pm 0.01$ & $0.10 \pm 0.01$ & $0.42 \pm 0.03$ & $0.34 \pm 0.02$ & $0.42 \pm 0.04$ & $0.41 \pm 0.02$ \\
\hline Mean stem diameter $(\mathrm{cm})$ & $12.4 \pm 0.5$ & $13.5 \pm 0.9$ & $3.99 \pm 0.13 \mathrm{~b}^{\mathrm{B}}$ & $4.09 \pm 0.14 \mathrm{~b}^{\mathrm{B}}$ & $4.65 \pm 0.14 \mathrm{a}^{\mathrm{B}}$ & $4.73 \pm 0.15 \mathrm{a}^{\mathrm{B}}$ \\
\hline Basal area $\left(\mathrm{m}^{2} \mathrm{ha}^{-1}\right)$ & 8.36 & 8.51 & 13.6 & 14.1 & 14.9 & 16.1 \\
\hline Mean stem height (m) & $8.18 \pm 0.37$ & $9.42 \pm 0.35$ & $2.41 \pm 0.03 \mathrm{a}^{\mathrm{B}}$ & $2.45 \pm 0.05 \mathrm{a}^{\mathrm{B}}$ & $1.95 \pm 0.06 \mathrm{~b}^{\mathrm{B}}$ & $2.01 \pm 0.06 \mathrm{~b}^{\mathrm{B}}$ \\
\hline \multicolumn{7}{|l|}{ Biomass } \\
\hline Stem $\left(\mathrm{kg} \mathrm{plant}^{-1}\right)$ & $20.9 \pm 3.4 b^{C}$ & $24.4 \pm 3.8 \mathrm{a}^{\mathrm{C}}$ & $2.13 \pm 0.18 a^{B}$ & $2.21 \pm 0.22 \mathrm{a}^{\mathrm{B}}$ & $1.85 \pm 0.12 \mathrm{a}^{\mathrm{B}}$ & $1.79 \pm 0.17 \mathrm{~b}^{\mathrm{B}}$ \\
\hline Branches (kg plant ${ }^{-1}$ ) & $8.9 \pm 1.3 \mathrm{a}^{\mathrm{C}}$ & $8.9 \pm 1.4 a^{c}$ & $1.11 \pm 0.12 \mathrm{a}^{\mathrm{B}}$ & $0.70 \pm 0.06 \mathrm{a}^{\mathrm{B}}$ & $0.99 \pm 0.05 \mathrm{a}^{\mathrm{B}}$ & $0.66 \pm 0.14 \mathrm{a}^{\mathrm{B}}$ \\
\hline Leaves $\left(\mathrm{kg} \mathrm{plant}^{-1}\right)$ & $5.2 \pm 1.0 \mathrm{a}^{\mathrm{C}}$ & $4.3 \pm 0.5 \mathrm{~b}^{\mathrm{C}}$ & $0.77 \pm 007 a^{B}$ & $0.54 \pm 0.06 b^{B}$ & $0.76 \pm 0.08 a^{B}$ & $0.73 \pm 0.12 \mathrm{a}^{\mathrm{B}}$ \\
\hline
\end{tabular}

A Maximum values of coffee LAI measured in September 2004 and October 2005.

${ }^{\text {B }}$ Different letters indicate significant difference $(P<0.05)$ between systems (AFS versus MC) within a year for coffee parameters.

C Different letters indicate significant differences $(P<0.05)$ between years for tree biomass components.

${ }^{d}$ Canopy storage capacity was estimated from data of LAI and mean values of leaf storage capacity for I. densiflora evaluated at $0.14 \mathrm{~kg} \mathrm{~m}^{-2}$ and for coffee at $0.09 \mathrm{~kg} \mathrm{~m}^{-2}$.

Shade increased significantly the width, length and area of individual coffee leaves in AFS compared to MC with mean values of $4.6 \pm 0.1 \mathrm{~cm}, 10.3 \pm 0.2 \mathrm{~cm}$ and $36.7 \pm 2.0 \mathrm{~cm}^{2}$ in AFS compared to $3.9 \pm 0.4 \mathrm{~cm}, 8.4 \pm 0.9 \mathrm{~cm}$ and $26.9 \pm 4.4 \mathrm{~cm}^{2}$ in MC. Nonetheless, the larger number of leaves per coffee plant in MC (Fig. 2) resulted in similar coffee LAI in both systems in the 2004 rainy season and higher LAI in MC than AFS in the 2005 rainy season. The total LAI (coffee + Inga) was higher in AFS (5.96) than in MC (4.71) in 2004 whereas closer values of 5.02 and 4.60 were found in 2005 for AFS and MC, respectively (Table 1 ).

The high coffee berry production in 2004 resulted in coffee branch dieback in early 2005, reducing the coffee branch and leaf biomasses especially in AFS. However, compared to MC, coffee plants under shade had greater stem height and longer branches (visual estimate) during the 2 year period and larger stem biomass especially in 2005. While canopies of adjacent coffee rows were distant from $50 \mathrm{~cm}$ to $80 \mathrm{~cm}$ in MC, they were wider and almost joined under the shade of I. densiflora leading to lower coffee canopy openness in AFS than in MC in 2005.

\subsection{Rainfall characteristics}

Annual rainfall was particularly high with $3245 \mathrm{~mm}$ during 2004 and $2684 \mathrm{~mm}$ during 2005 and hence quite larger than the historical site average of $2300 \mathrm{~mm}$. Rainfall was unevenly distributed throughout the year with $3057 \mathrm{~mm}$ (94\%) and $2495 \mathrm{~mm}$
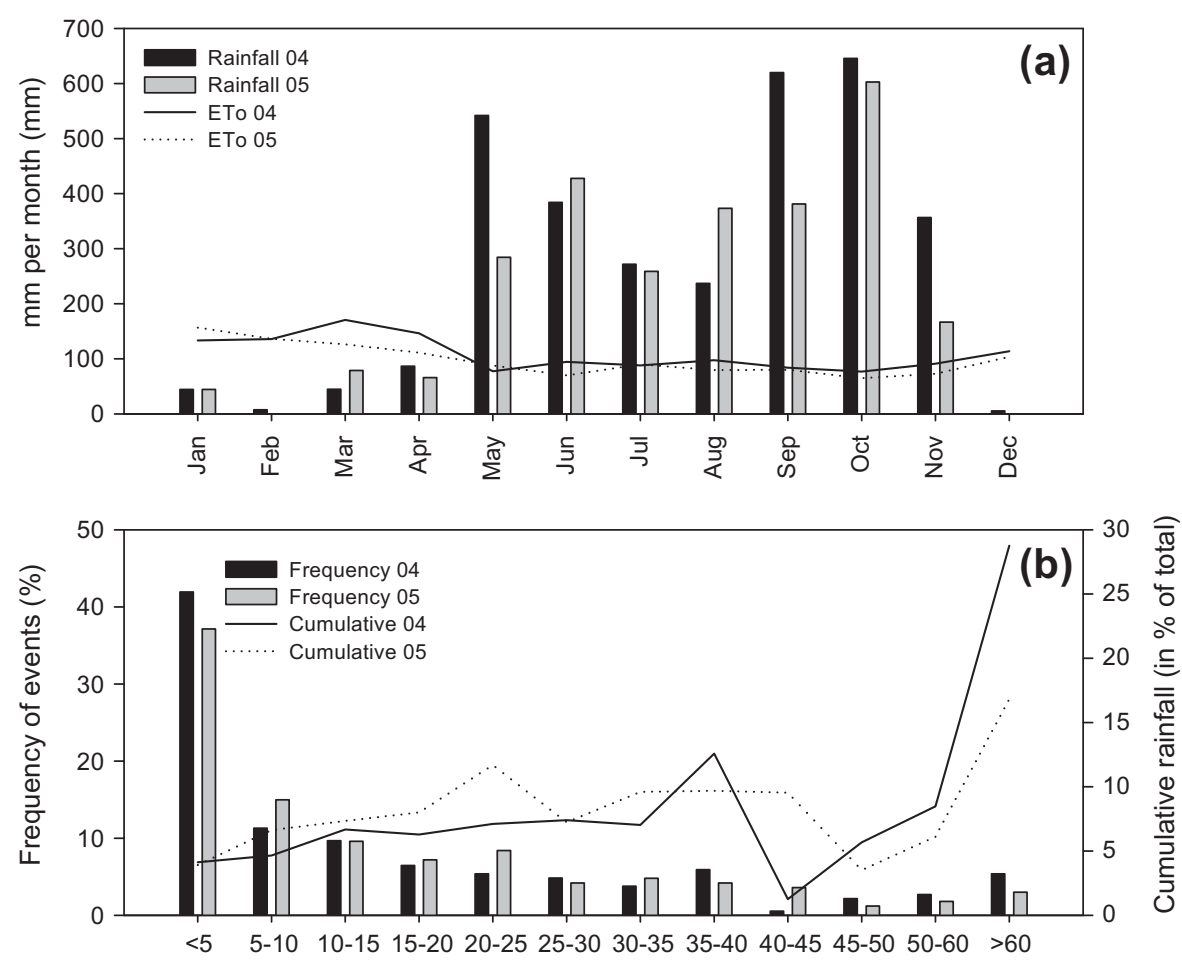

Rainfall ranges $\left(\mathrm{mm} \mathrm{d}^{-1}\right)$

Fig. 3. Rainfall characteristics at the research site in the Central Valley of Costa Rica in 2004 and 2005; (a) monthly rainfall and ETo; and (b) frequency and total annual rainfall in the different rainfall ranges. 
(93\%) during the wet season from May to November, in 2004 and 2005 , respectively. Due to the fact that daily rainfall occurred mainly during afternoon hours and for a relatively short duration, it is referred as "single rainfall event" registered the next morning. Indeed, most of the rainfall events ranging from $5 \mathrm{~mm}$ to $30 \mathrm{~mm}$ lasted between 2 and $3 \mathrm{~h}$ and daily rainfall higher than $30 \mathrm{~mm}$ lasted between 3 and $5 \mathrm{~h}$.

During the dry season (December to April), monthly rainfall ranged from $0 \mathrm{~mm}$ to $87 \mathrm{~mm}$ and averaged $50 \mathrm{~mm}$. During the rainy season, it ranged from $167 \mathrm{~mm}$ to $645 \mathrm{~mm}$ with the highest rainfall recorded in September and October (Fig. 3a). During the rainy season of $2004,41 \%$ of the single rainfall events were below $5 \mathrm{~mm}$ and contributed to a total of $133 \mathrm{~mm}$, while $5 \%$ were above $60 \mathrm{~mm}$ and contributed to a total of $933 \mathrm{~mm}$ (28\% of annual rainfall, Fig. 3b). During 2005, rainfall followed a similar pattern, but rainfall events above $60 \mathrm{~mm}$ only contributed to a total of $450 \mathrm{~mm}$ ( $17 \%$ of annual rainfall).

\section{Table 2}

Cumulative throughfall (expressed in percentage of gross rainfall) of the monitored period (June to September in 2004 and July to November in 2005) measured on coffee rows, at $0.5 \mathrm{~m}$ from the coffee row or at $1 \mathrm{~m}$ midway between coffee rows in a monoculture (MC) or an agroforestry system (AFS) with Inga densiflora, in the Central Valley of Costa Rica in 2004 and 2005 (Mean \pm standard error, $n=24$ ). Within a year (2004 or 2005), values followed by the same letter are not significantly different $(P<0.05)$.

\begin{tabular}{cllll}
\hline Year & System & Coffee row (\%) & $\begin{array}{l}\text { Coffee inter-row, } \\
\text { at } 50 \mathrm{~cm} \text { from } \\
\text { the row (\%) }\end{array}$ & $\begin{array}{l}\text { Midway between } \\
\text { coffee rows, at } 1 \mathrm{~m} \\
\text { from the row (\%) }\end{array}$ \\
\hline 2004 & AFS & $54.1 \pm 4.2 \mathrm{~b}$ & $60.5 \pm 3.4 \mathrm{~b}$ & $93.8 \pm 4.0 \mathrm{a}$ \\
& MC & $64.3 \pm 15.2 \mathrm{~b}$ & $92.3 \pm 9.7 \mathrm{a}$ & $97.5 \pm 2.6 \mathrm{a}$ \\
2005 & AFS & $72.9 \pm 3.9 \mathrm{~b}$ & $71.6 \pm 3.6 \mathrm{~b}$ & $93.2 \pm 2.8 \mathrm{a}$ \\
& MC & $71.0 \pm 3.5 \mathrm{~b}$ & $87.7 \pm 3.1 \mathrm{a}$ & $93.0 \pm 2.6 \mathrm{a}$ \\
\hline
\end{tabular}

Table 3

Cumulative throughfall (expressed in percentage of gross rainfall) of the monitored period (June to September in 2004 and July to November in 2005) measured at four distance ranges (a, b, c and d as shown in Fig. 1) from the base of the nearest shade tree (Inga densiflora) in an agroforestry system (AFS) in the Central Valley of Costa Rica (Mean (18) \pm standard error). Within a year, mean values followed by the same letter are not significantly different $(P<0.05)$.

\begin{tabular}{lllll}
\hline Distance ranges from the tree $(\mathrm{m})$ & \multicolumn{3}{l}{ Year } & \\
\cline { 2 - 5 } & 2004 & & 2005 & \\
\hline (a) $0.5-1.4$ & $71.2 \pm 7.4$ & a & $74.7 \pm 5.4$ & a \\
(b) $2.1-3.1$ & $73.0 \pm 8.3$ & a & $75.3 \pm 4.4$ & a \\
(c) $2.5-3.1$ & $72.4 \pm 20.2$ & a & $77.1 \pm 6.2$ & a \\
(d) $3.2-4.2$ & $74.6 \pm 6.8$ & a & $80.6 \pm 7.8$ & a \\
\hline
\end{tabular}

Monthly ETo varied between 70 and $170 \mathrm{~mm}$ and was higher than rainfall during the dry months (Fig. 3a). Annual ETo amounted to 1310 and $1178 \mathrm{~mm}$ for 2004 and 2005, respectively.

\subsection{Throughfall}

Spatial distribution of throughfall depended on the distance to the coffee row; smallest values were recorded on the rows and largest ones at $1 \mathrm{~m}$ from the rows, i.e. midway between rows (Table 2). Only in AFS, throughfall at $50 \mathrm{~cm}$ from the coffee row, was significantly lower than at midway between the coffee rows. As a result of longer coffee branches in AFS, throughfall measured at $50 \mathrm{~cm}$ from the coffee row was smaller in AFS than in MC (Table 2). Although a trend could be observed indicating an increasing throughfall with increasing distance ranges of coffee plants to shade trees, no statistical differences were observed and hence distance ranges had no significant impact on throughfall (Table 3).

The spatial variability in throughfall was quite large in both systems, particularly in AFS. As a general trend, the coefficient of variation (CV = standard deviation/mean) of throughfall (expressed as a fraction of rainfall) decreased with increasing rainfall. This CV was larger for gross rainfall below $5 \mathrm{~mm}$ with values of $76 \%$ and $67 \%$ for AFS and MC, respectively, decreased down to $22 \%$ and $16 \%$ for AFS and MC, respectively, for gross rainfall between 5 and $10 \mathrm{~mm}$, and remained almost constant at $12 \%$ for larger rainfalls. These tendencies were clearly visible from data presented in Table 4, i.e. decreasing values of standard error with increasing values of means.

A strong and positive linear relationship was detected between throughfall and gross rainfall in both systems and for both years (Fig. 4a and b). Regression equations of throughfall versus gross rainfall were computed for 86 and 140 single rain events for 2004 and 2005, respectively, with throughfall values ranging from $0.25 \mathrm{~mm}$ to $60 \mathrm{~mm}$. Regression slopes were significantly higher $(P<0.05)$ in MC than in AFS during the two consecutive years whereas intercepts were similar. During the monitored periods of 2004 (June to September) and 2005 (July to November), cumulative throughfall was $85.1 \%$ and $83.2 \%$ of gross rainfall in MC and $72.8 \%$ and $76.8 \%$ in AFS (Table 5). Compared to MC, AFS resulted in significantly smaller total throughfall during both years with a more important difference in 2004.

\subsection{Coffee stemflow}

The variability in coffee stemflow measured in 2005 greatly depended upon the gross rainfall and was higher in AFS than in MC. The average CV was $0.36( \pm 0.11)$ in AFS and $0.29( \pm 0.10)$ in MC for rainfall above $5 \mathrm{~mm}$. In general, coffee stemflow was very low for rainfall events below $5 \mathrm{~mm}$, approaching 0 for rainfall below

Table 4

Throughfall, stemflow and canopy interception loss expressed as the percentage of daily gross rainfall following ranking into seven rainfall ranges (in mm $\mathrm{d}^{-1}$ ) in two coffee systems (MC: monoculture and AFS: coffee agroforestry system with Inga densiflora) in the Central Valley of Costa Rica in 2005. N is the number of rainfall events (Mean \pm standard error).

\begin{tabular}{|c|c|c|c|c|c|c|c|c|}
\hline \multirow[t]{3}{*}{ Rainfall ranges } & \multirow[t]{3}{*}{$N$} & \multicolumn{2}{|c|}{$\%$ Throughfall } & \multicolumn{3}{|l|}{ \% Stemflow } & \multicolumn{2}{|c|}{$\%$ Interception } \\
\hline & & \multirow[t]{2}{*}{ AFS } & \multirow[t]{2}{*}{ MC } & \multicolumn{2}{|l|}{ AFS } & \multirow{2}{*}{$\begin{array}{l}\text { MC } \\
\text { Coffee }\end{array}$} & \multirow[t]{2}{*}{ AFS } & \multirow[t]{2}{*}{ MC } \\
\hline & & & & I. densiflora & Coffee & & & \\
\hline$<1$ & 12 & $24.3 \pm 8.7$ & $27.6 \pm 8.4$ & 0 & 0 & 0 & $74.8 \pm 8.9$ & $71.9 \pm 8.4$ \\
\hline $1-5$ & 20 & $46.6 \pm 7.9$ & $51.3 \pm 7.7$ & $0.4 \pm 0.4$ & $1.5 \pm 0.6$ & $1.0 \pm 0.4$ & $51.5 \pm 8.2$ & $47.8 \pm 7.7$ \\
\hline $5-10$ & 16 & $72.0 \pm 4.0$ & $73.1 \pm 3.0$ & $1.0 \pm 0.4$ & $8.6 \pm 1.0$ & $5.6 \pm 0.5$ & $18.3 \pm 4.7$ & $21.3 \pm 3.0$ \\
\hline $10-20$ & 15 & $75.4 \pm 2.6$ & $81.9 \pm 2.9$ & $1.0 \pm 0.3$ & $10.5 \pm 0.6$ & $7.4 \pm 0.4$ & $13.2 \pm 2.8$ & $10.7 \pm 3.1$ \\
\hline $20-30$ & 12 & $77.9 \pm 3.8$ & $81.4 \pm 3.7$ & $1.1 \pm 0.2$ & $9.8 \pm 1.0$ & $7.4 \pm 0.4$ & $11.2 \pm 3.8$ & $11.2 \pm 3.9$ \\
\hline $30-40$ & 8 & $80.5 \pm 1.1$ & $84.9 \pm 2.0$ & $0.5 \pm 0.1$ & $10.2 \pm 1.5$ & $7.2 \pm 1.0$ & $8.7 \pm 2.1$ & $8.0 \pm 1.7$ \\
\hline$>40$ & 13 & $80.4 \pm 3.5$ & $85.3 \pm 3.3$ & $1.9 \pm 0.2$ & $10.6 \pm 0.1^{\mathrm{a}}$ & $7.7 \pm 0.1^{\mathrm{a}}$ & $7.2 \pm 3.5^{\mathrm{a}}$ & $7.0 \pm 3.3^{\mathrm{a}}$ \\
\hline
\end{tabular}

${ }^{\text {a }}$ Values were extrapolated from the relationships presented in Table 2. 


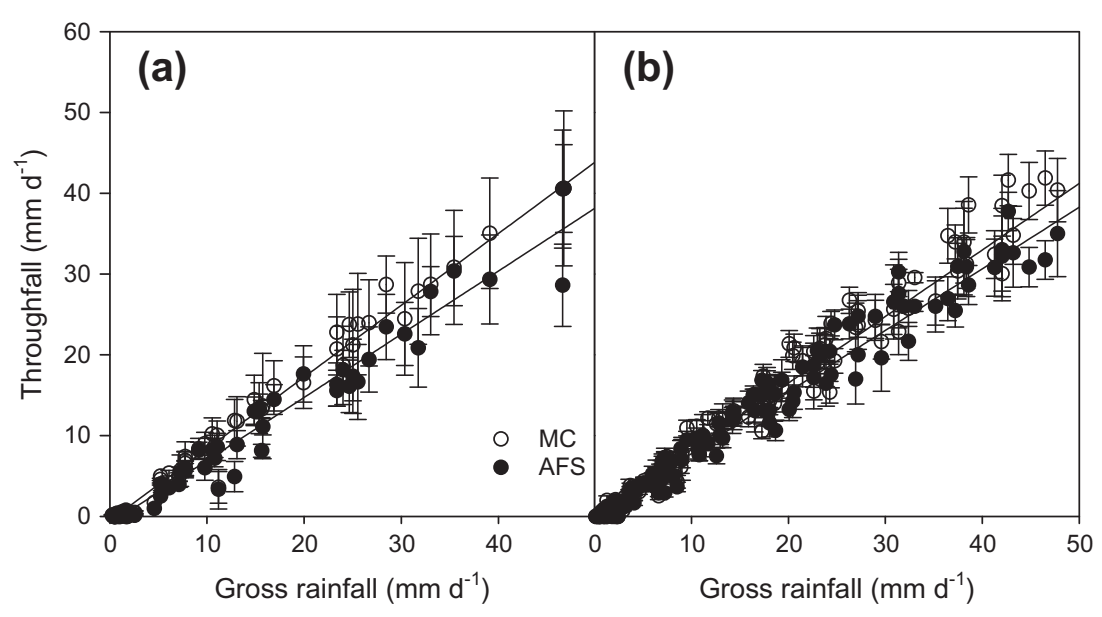

Fig. 4. Mean (average value from 72 rain gauges) throughfall ( $T F \pm$ standard deviation) as a function of gross rainfall (GR) in 2004 (a) and 2005 (b) in two coffee systems (MC: monoculture and AFS: coffee agroforestry system with Inga densiflora) in the Central Valley of Costa Rica (for 2004, MC: $r^{2}=0.99$, TF $=-0.59+0.90 *$ GR; AFS: $r^{2}=0.97$, $\mathrm{TF}=-0.85+0.78 * \mathrm{GR}$; for $2005, \mathrm{MC}: r^{2}=0.97, \mathrm{TF}=-0.53+0.87 * \mathrm{GR}$; AFS: $\left.r^{2}=0.97, \mathrm{TF}=-0.45+0.80 * \mathrm{GR}\right)$. Within a year $(2004$ or 2005$)$ regression slopes were significantly different at $P<0.05$.

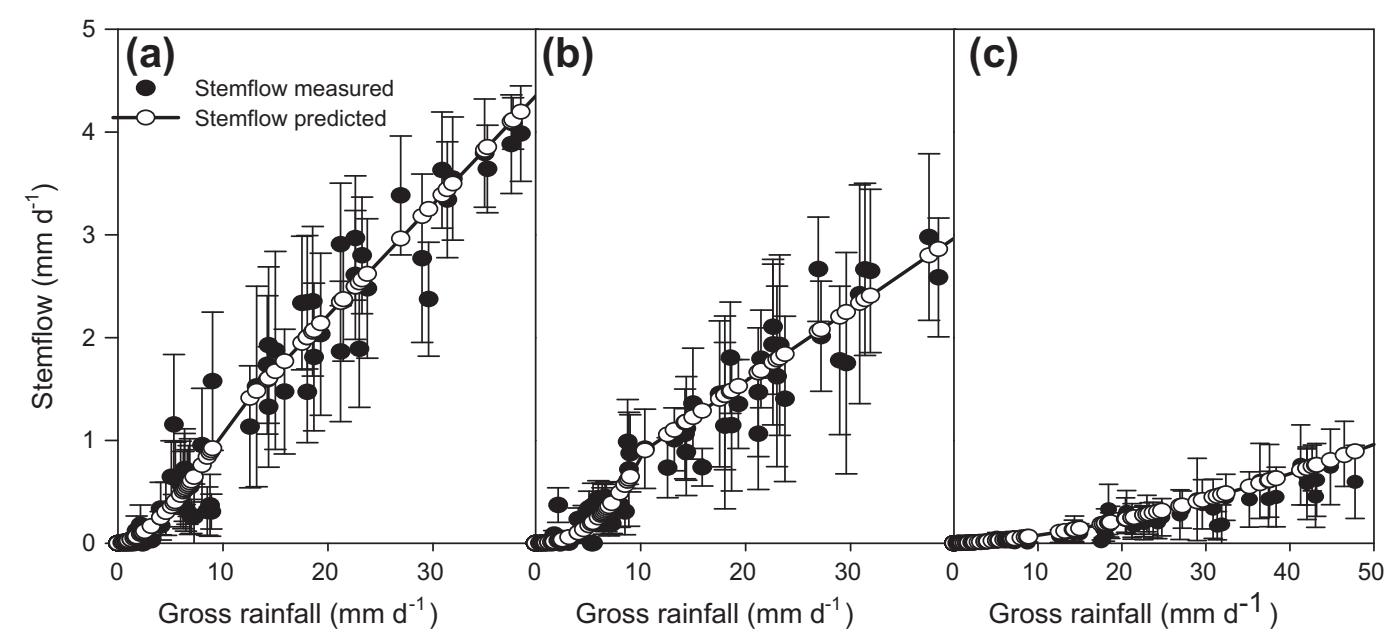

Fig. 5. Stemflow (Mean \pm standard deviation) as a function of gross rainfall for (a) coffee in an agroforestry system (AFS), (b) coffee in monoculture (MC), and (c) Inga densiflora in AFS in the Central Valley of Costa Rica in 2005. A power function was applied for rainfall $<10 \mathrm{~mm}$ and a linear function for rainfall $>10 \mathrm{~mm}$ (see Table 6 ).

$2.5 \mathrm{~mm}$ (Table 4). For rainfall above $5 \mathrm{~mm}$, stemflow (expressed as a fraction of gross rainfall) varied from $8.6 \%$ to $10.6 \%$ and from $5.6 \%$ to $7.7 \%$ in AFS and MC respectively (Table 4 ) with a relative measurement accuracy of $1.5 \%$ of gross rainfall in AFS and $1 \%$ in MC. In both systems, the relationship between measured stemflow and gross rainfall could be described as a power function for rainfall $<10 \mathrm{~mm}$ and a linear function for rainfall $>10 \mathrm{~mm}$ (Fig. $5 \mathrm{a}$ and b; Table 6). With 91 rainfall events monitored in 2005 (1725 mm), cumulative values of stemflow were larger in AFS than in MC representing $10.6 \%$ and $7.2 \%$ of gross rainfall, respectively (Table 5 ).

\subsection{Inga stemflow}

In general, Inga stemflow was very low in AFS (below $1.2 \mathrm{~mm}$ for the largest rainfall events); this was due to the low density of trees $\left(277\right.$ trees ha $\left.{ }^{-1}\right)$ compared to that of coffee $\left(\sim 5000 \mathrm{ha}^{-1}\right)$. Most rainfall events below $5 \mathrm{~mm}$ did not result in any tree stemflow (Table 4). For rainfalls below $15 \mathrm{~mm}$, tree stemflow was very low (below $0.5 \%$ of rainfall). The relationship between measured tree stemflow and gross rainfall was described by a power function
(Fig. 5c, Table 6). Cumulative stemflow was $20.7 \mathrm{~mm}$ for the monitored period of 2005 , i.e. $1.2 \%$ of gross rainfall (Table 5 ).

\subsection{Funneling ratio of coffee plants and shade trees}

Due to their V-shape and compact architecture and upward inclination of branches, coffee plants operated as a rather efficient funnel with high FR values of 68 and 48 in AFS and MC, compared to FR values of 20 for I. densiflora.

\subsection{Canopy interception loss}

During the monitored period (July to November 2005), canopy interception loss (expressed as \% of gross rainfall) reached values close to $75 \%$ for small rainfalls $(<1 \mathrm{~mm})$, up to $50 \%$ for rainfalls around $5 \mathrm{~mm}$ and down to less than $10 \%$ for heavier rain $(>30 \mathrm{~mm})$. Consequently, interception loss varied from $75 \%$ to $7.2 \%$ and from $72 \%$ to $7 \%$ for AFS and MC, respectively, depending on rainfall amount (Table 4). In both systems, the relationship between interception loss and gross rainfall was represented by a 
Table 5

Cumulative rainfall, throughfall, stemflow and canopy interception for the monitored periods (June to September 2004 and July to November 2005) in two coffee systems (MC: monoculture and AFS: agroforestry system with Inga densiflora) in the Central Valley of Costa Rica (Mean \pm standard error).

\begin{tabular}{|c|c|c|c|c|c|c|c|c|c|}
\hline \multirow[t]{3}{*}{ Year system } & \multirow{3}{*}{$\begin{array}{l}\text { Period rainfall } \\
(\mathrm{mm})\end{array}$} & \multirow{2}{*}{\multicolumn{2}{|c|}{ Throughfall }} & \multicolumn{4}{|c|}{ Stemflow } & \multirow{2}{*}{\multicolumn{2}{|c|}{ Interception }} \\
\hline & & & & \multicolumn{2}{|l|}{ Coffee } & \multicolumn{2}{|l|}{ Tree } & & \\
\hline & & $(\mathrm{mm})$ & $(\%)$ & $(\mathrm{mm})$ & $(\%)$ & $(\mathrm{mm})$ & $(\%)$ & $(\mathrm{mm})$ & $(\%)$ \\
\hline \multicolumn{10}{|l|}{2004} \\
\hline AFS & 1426 & 1038 & $72.8 \pm 6.3$ & - & - & - & - & - & - \\
\hline MC & 1426 & 1214 & $85.1 \pm 2.6$ & - & - & - & - & - & - \\
\hline \multicolumn{10}{|l|}{2005} \\
\hline AFS & 1725 & 1324 & $76.8 \pm 2.0$ & 183 & $10.6 \pm 1.1$ & 21 & $1.2 \pm 0.3$ & 196 & 11.4 \\
\hline MC & 1725 & 1434 & $83.2 \pm 1.9$ & 124 & $7.2+0.6$ & - & - & 167 & 9.6 \\
\hline
\end{tabular}

Table 6

Coefficients of regression of daily stemflow versus gross rainfall $\left(P_{g}\right)$ in two different coffee systems (MC: monoculture and AFS: agroforestry system with Inga densiflora) in the Central Valley of Costa Rica. For daily coffee stemflow with small daily rainfall $<10 \mathrm{~mm}\left(S_{\mathrm{CS}}\right.$ in $\left.\mathrm{mm} \mathrm{d}^{-1}\right)$, the equation is $S_{\mathrm{CS}}=a \times P_{g}^{b}$. For daily coffee stemflow for large daily rainfall $>10 \mathrm{~mm}\left(S_{\mathrm{CL}}\right.$ in $\left.\mathrm{mm} \mathrm{d}^{-1}\right)$, the equation is $S_{\mathrm{CL}}=a+b \times P_{g}$. For daily Inga tree stemflow $\left(S_{\mathrm{I}}\right.$ in $\left.\mathrm{mm} \mathrm{d}^{-1}\right)$, the equation is $S_{\mathrm{I}}=a \times P_{g}{ }^{b} . N$ is the number of rainfall events.

\begin{tabular}{lllllll}
\hline Coffee system & $a$ & $b$ & $b$ standard error & $R^{2}$ & $N$ & $P$ \\
\hline$M C$ & & & & & & \\
Coffee $\left(S_{\mathrm{CS}}\right)$ & 0.004 & 2.313 & 0.495 & 0.92 & 82 & 0.0001 \\
Coffee $\left(S_{\mathrm{CL}}\right)^{\mathrm{a}}$ & 0.176 & 0.068 & 0.005 & & & 0.0001 \\
AFS & & & & & & \\
Coffee $\left(S_{\mathrm{CS}}\right)$ & 0.025 & 1.641 & 0.303 & 0.95 & 82 & 0.0001 \\
Coffee $\left(S_{\mathrm{CL}}\right)^{\mathrm{a}}$ & 0.054 & 0.106 & 0.006 & & & 0.0001 \\
Inga $\left(S_{\mathrm{I}}\right)^{\mathrm{a}}$ & 0.002 & 1.578 & 0.077 & 0.93 & 102 & 0.0001 \\
\hline
\end{tabular}

a Note that the upper limit of the regression for coffee stemflow is $45 \mathrm{~mm}$ while the upper limit of the Inga stemflow is $60 \mathrm{~mm}$.

hyperbolic equation (Fig. 6). The percentage of canopy interception loss decreased with increasing rainfall from $5 \mathrm{~mm}$ to $45 \mathrm{~mm}$ while the percentage of stemflow remained almost constant (Table 4). Consequently, throughfall increased from $24.3 \%$ and $27.6 \%$ for rainfall events below $1 \mathrm{~mm}$ to $80.4 \%$ and $85.3 \%$ for rainfall events above $40 \mathrm{~mm}$ for AFS and MC, respectively (Table 4). Although canopy interception loss was large for rainfall events below $5 \mathrm{~mm}$, in cumulative term it only represented $13 \%$ and $15 \%$ of the total interception for AFS and MC, respectively. On the other hand, for rainfall events above $40 \mathrm{~mm}$ the cumulative values of canopy interception loss represented $34 \%$ and $30 \%$ of the total interception for AFS and $\mathrm{MC}$, respectively. As the daily measurements of throughfall were performed only once in the following morning and sometimes several rainfall events occurred during the same day, this did not allow us to relate rain interception with rainfall intensity that was monitored every $1 / 4 \mathrm{~h}$. In 2005, cumulated throughfall, stemflow and interception were found to represent $76.8 \%, 11.8 \%$ and $11.4 \%$ for AFS and $83.2 \%, 7.2 \%$ and $9.6 \%$ for MC (Table 5 ).

\section{Discussion}

\subsection{Throughfall}

Lower throughfall in AFS compared to MC may be explained by differences in canopy structure: namely lower canopy openness and higher total LAI (shade tree and coffee) in AFS compared to MC. During the monitoring period from July to November 2005 coffee LAI increased rapidly to approximately the values reported in table 1 . To investigate the effect of differences in LAI on rainfall partitioning, the early rainy period of July + August was dissociated from the second part of the rainy season 2005. It can be seen (Fig. 7) that a large part of the throughfall differences between these two monitoring periods and cultivation systems may be explained by differences in total LAI $\left(R^{2}=0.52, P<0.10\right)$. Canopy cover or LAI are known to influence canopy storage capacity, throughfall and evaporation (Tobon Marin et al., 2000; Huber and Iroumé, 2001). The present values of cumulative throughfall (73-85\% of gross rainfall in AFS and MC respectively) were within the ranges reported by Tobon Marin et al. (2000) and Huber and Iroumé (2001) for various forest types with values of $55-90 \%$ depending on canopy structure and climatic conditions. Our results are in agreement with those of Jaramillo and Chaves $(1998,1999)$ that reported throughfall values in coffee AFS with Inga sp $10 \%$

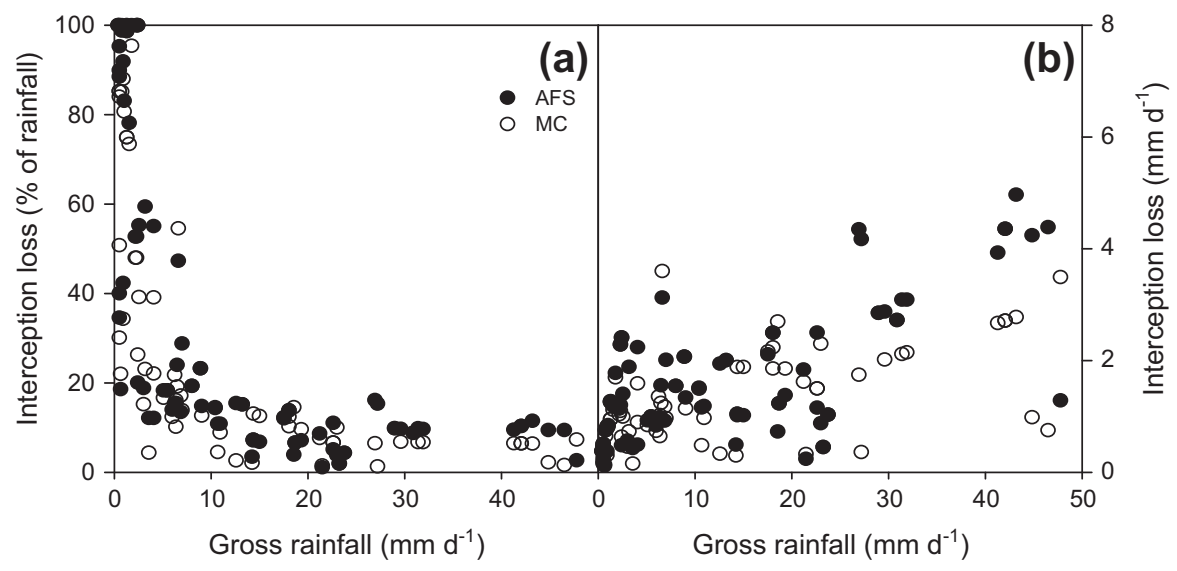

Fig. 6. Rainfall loss through canopy interception as a function of gross rainfall in an agroforestry system (AFS) and coffee monoculture (MC) in the Central Valley of Costa Rica for the monitored period from July to November 2005. 


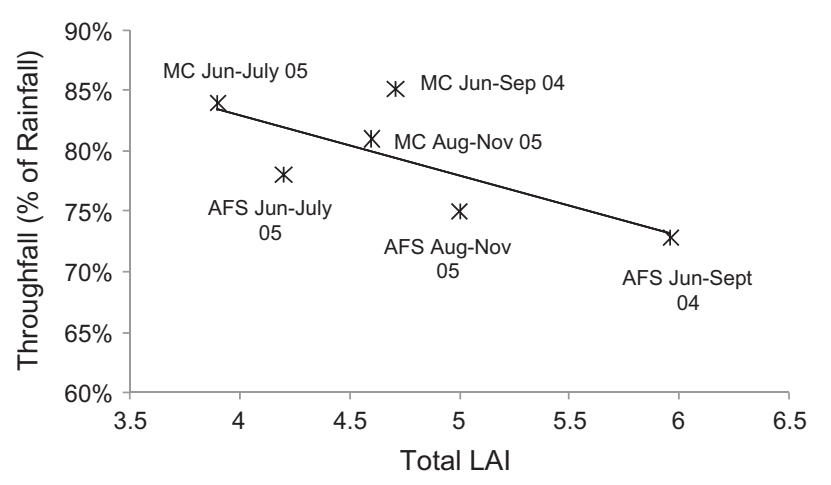

Fig. 7. Cumulative throughfall (TF) as a function of total LAI in two coffee systems (MC: monoculture and AFS: coffee agroforestry system with Inga densiflora) at different periods in 2004 and 2005 in the Central Valley of Costa Rica, TF (\% of rainfall $)=-0.0494 \mathrm{LAI}+1.0267\left(R^{2}=0.52, P=0.10\right)$.

lower than in coffee MC. Furthermore, the present results are also consistent with data from shaded coffee with Eucalyptus deglupta (110 trees $\mathrm{ha}^{-1}$ ) at a lower altitude zone of Costa Rica, where throughfall represented $83 \%$ in coffee MC and $82 \%$ in AFS for respective LAI values of 2.74 and 3.5 (Harmand et al., 2007). In those systems, the coffee plants were younger ( 2.5 years old) with smaller LAI and greater coffee canopy openness than in the present situation. In our study, the multi-layer canopy nature of AFS could have been analyzed more thoroughly with additional measurements of throughfall below the shade trees and above the coffee layer to quantify separately the contribution to throughfall of coffee plants and shade trees.

\subsection{Stemflow}

The present study is the first one to monitor stemflow in coffee plantations. A power relationship was observed between stemflow and gross rainfall over the full rainfall range for shade trees, but only for daily rainfall below $10 \mathrm{~mm}$ in the case of coffee stemflow. At higher rainfall values $(>10 \mathrm{~mm})$ a linear relationship was observed. Tobon Marin et al. (2000) also found power functions for stemflow in different forest ecosystems of Amazonia. Coffee stemflow represented up to $10 \%$ of rainfall and should not be ignored when computing water budget at plot scale. In AFS, coffee stemflow accounted for $90 \%$ of total stemflow (11.8\% of rainfall). This value felt within the range (8-18\%) mentioned by Levia and Frost (2003) for smaller-stature forests or forests with a large proportion of small or multiple stem trees (Levia and Frost, 2003). In a rainforest of Borneo, Odair et al. (2004) observed that the understory composed of small trees represented $77 \%$ of total stemflow. For cocoa plantations, Levia and Frost (2003) reported cumulative stemflow of only $2 \%$ which was probably due to cocoa tree architecture (less compact than coffee) and density (generally in the range of 1000-1500 cocoa plants ha ${ }^{-1}$ compared to over 4500 coffee plants $\mathrm{ha}^{-1}$ ). On the other hand, high stemflow values ranging from $18 \%$ to $26 \%$ of incident rainfall were reported by Cattan et al. (2007a) for banana plantations ( 1810 plants ha ${ }^{-1}$ ). In this plantation with high funneling effect, each banana plant concentrated 4-6 times more rainwater at the base of its stem than a coffee plant did in our study.

FR values of 68 and 48 for coffee plants in AFS and MC, and values of 20 for I. densiflora were in the middle range of values (7112) reported by Levia and Frost (2003). Difference in FR between AFS and MC were probably due to the differences in the architecture of the coffee plants between systems. Shaded coffee plants were generally $40 \mathrm{~cm}$ taller with longer branches than in MC. Indeed, coffee architecture, not LAI, appeared to be the main driver of stemflow as stemflow of shaded coffee plants in 2005 was higher than that of plants in MC (Table 4), despite the fact that these shaded plants had lower LAI (Table 1). In other studies (Levia and Frost, 2003), a positive relationship was observed between stem length and stemflow, presumably taller plants produced greater stemflow through greater projected stem surface area. Longer length of coffee stems and branches and the presence of shade trees resulted in a total cumulative stemflow of $11.8 \%$ of rainfall in AFS compared to $7.2 \%$ in MC.

\subsection{Canopy interception loss and rainfall partitioning}

Even though throughfall and gross rainfall were highly correlated $(r=0.98)$, the relationship between gross rainfall and canopy interception was less prominent, with lower correlation coefficients ( 0.66 and 0.67 for AFS and MC, respectively). In other words, throughfall could be predicted with higher accuracy based on rainfall amounts than canopy interception, due to the fact that canopy interception was not measured directly but calculated as the difference between gross rainfall in the open and the measured throughfall plus stemflow. Daily values of canopy interception loss ranged from $0.25 \mathrm{~mm}$ to $6.5 \mathrm{~mm}$ and from $0.25 \mathrm{~mm}$ to $5.0 \mathrm{~mm}$ in AFS and MC, respectively. These values of canopy interception loss were very high and of the same order of magnitude or higher than ETo. Indeed, daily canopy interception losses, up to $6 \mathrm{~mm}$, were mostly registered during heavy rain periods when ETo values were below $2.5 \mathrm{~mm}$. Carlyle-Moses (2004), reported that evaporation from the canopy during gross precipitation events is often significant and the dominant component of canopy interception loss. To sustain the relatively high evaporation rates, the authors suggested a downward sensible heat flux from above the vegetation which is generated as intercepted precipitation evaporates and cools the canopy. Accordingly, Tóbon Marin et al. (2000) found daily values of interception loss of $7 \mathrm{~mm}$ from a wet forest canopy in the Central Amazonia and estimated the mean evaporation during rainfall events at $0.47 \mathrm{~mm} \mathrm{~h}^{-1}$. Nevertheless, it must be stressed that our study and these previous studies on interception loss in different ecosystems did not bring any independent validation of evapotranspiration through direct measurements of energy balance closure. Only these micrometeorological measurements would provide evaluation of errors due to sampling of throughfall + stemflow and to accumulation of water in vegetation that could be evaporated in the days following the rainfall event.

The associated trees affected the partitioning of gross rainfall, reducing throughfall and increasing stemflow, through their direct effect on interception and their indirect effect on coffee architecture. By modifying coffee architecture, shade trees reduced the coffee canopy openness and increased the funneling ratio of coffee plants resulting in lower throughfall and higher coffee stemflow rates under shade than in MC. Nevertheless, total interception was only slightly increased in AFS ( $11.4 \%$ of rainfall) compared to MC (9.6\% of rainfall) in 2005 (Table 5) which can be related to a low overall increase of LAI of the system (from 4.6 in MC to 5.02 in AFS in 2005). Those values of interception loss are slightly lower than that reported by Tobon Marin et al. (2000) for forests of Western Amazonia, with values ranging from $12 \%$ to $17 \%$ of the rainfall depending on the forest canopy cover.

\section{Conclusion}

This study showed a small influence in introducing shade trees of I. densiflora ( 278 trees ha ${ }^{-1}$ with mean height of $9 \mathrm{~m}$ ) on the total interception loss measured when the total LAI of AFS remained similar to that of coffee MC. Furthermore, coffee LAI was more than 3 -fold that of shade trees, and hence coffee accounted for the 
largest part of interception loss. This study also demonstrated that coffee stemflow is far from negligible with $7 \%$ and $10 \%$ of annual rainfall in MC and under the shade of Inga trees, respectively. Furthermore, coffee architecture, not LAI, appeared to be the main driver of stemflow. The associated tree created a second canopy layer, but even more importantly modified coffee architecture, increasing the length of coffee stems and branches which resulted in higher coffee funneling ratios under shade. This translated into a decrease in throughfall, but an enhanced stemflow in AFS. Under high rainfall, the funneling effect presently observed in coffee plants could enhance runoff as it leads to concentrating rainwater on a limiting area, as shown by Cattan et al. (2009) for banana plantations. However, the present study showed that this funneling effect is 4-6 times lower in coffee than in banana plantations, hence suggesting a lower potential detrimental effect on runoff. Furthermore, this funneling effect may increase percolation fluxes under plants (Cattan et al., 2007b). Runoff can also be reduced under shade trees through an improved soil surface status (e.g. larger litter cover). Thus, additional studies are needed to assess the influence of the modified stemflow and soil surface status by coffee plants and shade trees on runoff and infiltration.

\section{Acknowledgments}

The authors would like to thank the Coffee Institute of Costa Rica for facilitating the use and maintenance of the experimental plot in Barva de Heredia; Etienne Dambrine from INRA, Nancy, France, for helpful suggestions regarding the throughfall design, and the European Commission (ICA-4-CT-2001-10071) for their financial support of the scientific equipment and field measurements performed within the framework of the CASCA project (Coffee Agroforestry in Central America).

\section{References}

Allen, R.G., Pereira, L.S., Raes, D., Smith, M. 1998. Crop Evaporation: Guidelines for Computing Crop Water Requirements. FAO Irrigation and Drainage Paper No. 56. FAO, Rome, 300 pp.

Beer, J., Muschler, R., Kass, D., Somarriba, E., 1998. Shade management in coffee and cacao plantations. Agroforestry Systems 38, 139-164.

Carlyle-Moses, D.E., 2004. Throughfall, stemflow and canopy interception loss fluxes in a semi-arid Sierra Madre Oriental matorral community. Journal of Arid Environments 58, 181-202.

Cattan, P., Bussiere, F., Nouvellon, A., 2007a. Evidence of large rainfall partitioning patterns by banana and impact on surface runoff generation. Hydrological Processes 21, 2196-2205.

Cattan, P., Voltz, M., Cabidoche, Y.-M., Lacas, J.-G., Sansoulet, J., 2007b. Spatial and temporal variations in percolation fluxes in a tropical andosol influenced by banana cropping patterns. Journal of Hydrology 335, 157-169.

Cattan, P., Ruy, S.M., Cabidoche, Y.-M., Findeling, A., Desbois, P., Charlier, J.B., 2009. Effect on runoff of rainfall redistribution by the impluvium-shaped canopy of banana cultivated on an Andosol with a high infiltration rate. Journal of Hydrology 368, 251-261.

Fournier, L.A., 1988. El cultivo del café (Coffea arabica L.) al sol o a la sombra: un enfoque agronómico y eco fisiológico. Agronomía Costarricense 12, 131-146.

Frazer, G.W., Canham, C.D., and Lertzman, K.P. 1999. Gap Light Analyzer (GLA) Version 2.0: Imaging software to extract canopy structure and gap light transmission indices from true-colour fisheye photographs, users manual and program documentation. Copyright (c) 1999: Simon Fraser University, Burnaby, British Columbia, and the Institute of Ecosystem Studies, Millbrook, New York. $<$ www.ecostudies.org/gla/>.

Hall, R.L., 2003. Interception loss as a function of rainfall and forest types: stochastic modeling for tropical canopies revisited. Journal of Hydrology 280, 1-12.

Harmand, J.M., Ávila, H., Dambrine, E., Skiba, U., De Miguel Magaña, S., Renderos Durán, R.V., Oliver, R., Jiménez, F., Beer, J., 2007. Nitrogen dynamics and soil nitrate retention in a Coffea arabica - Eucalyptus deglupta agroforestry system in Southern Costa Rica. Biogeochemistry 85, 125-139.

Hölsher, D., Kohler, L., van Dijk, A.I.J.M., Bruijnzeel, L.A., 2004. The importance of epiphytes to total rainfall interception by a tropical montane rain forest in Costa Rica. Journal of Hydrology 292, 308-322.

Huber, A., Iroumé, A., 2001. Variability of annual rainfall partitioning for different sites and forest cover in Chile. Journal of Hydrology 248, 78-92.

Imbach, A.C., Fassbender, H.W., Borel, R., Beer, J., Bonmnemann, A., 1989. Modelling agroforestry systems of cacao (Theobroma cacao) with laurel (Cordia alliodora) and cacao with poro (Erythrina poeppigiana) in Costa Rica. IV. Water balances, nutrient inputs and leaching. Agroforestry Systems 8 (3), 267-287.

Jaramillo, A.. Chaves, B., 1998. Intercepcion de la lluvia en un bosque y en plantaciones de Coffea arabica L. Cenicafe 42, 129-135.

Jaramillo, A., Chaves, B., 1999. Aspectos hidrológicos en un bosque y en plantaciones de café (Coffea arabica L.) al sol y bajo sombra. Cenicafe 50, 97-105.

Jaramillo, A., 2003. La lluvia y el transporte de nutrimentos dentro de ecosistemas de bosque y cafetales. Cenicafe 54, 134-144.

Jiménez, A.E., Goldberg, D., 1992. Estudios ecologicos del agrosistema cafetalero. III. Efecto de differentes estructuras vegetales sobre el balance hidrico del cafetal. In: Jiménez, A.E., Gomez, P.A. (Eds.), Estudios Ecologicos en Agroecosistema Cafetalero. Editora Continental, Cuidad de Mexico, Mexico, pp. 39-54.

Jimenez, O.F., Lhomme, J.P., 1994. Rainfall interception and radiation regime in a plantation canopy. Fruits 49, 133-139.

Levia, D.F., Frost, E.E., 2003. A review and evaluation of stemflow literature in the hydrological and biogeochemical cycles of forested and agricultural ecosystems. Journal of Hydrology 274, 1-29.

Mata, R., Ramirez, J., 1999. Estudio de caraterizacion de suelos y su relacion con el manejo del cultivo de café en la provincia de Heredia. ICAFE, San Jose, Costa Rica. 92 pp.

Odair, J., Manfroi, K.K., Tanaka, N., Suzuki, M., Michiko, N., Tohru, N., Lucy, C., 2004 The stemflow of trees in a Bornean lowland tropical forest. Hydrological Processes 18 (13), 2455-2474.

Siles, P., Harmand, J.M., Vaast, P., 2010. Effects of Inga densiflora on the microclimate of coffee (Coffea arabica L) and overall biomass under optimal growing conditions in Costa Rica. Agroforestry Systems 78, 269-286.

Tobon Marin, C., Bouten, W., Sevink, J., 2000. Gross rainfall and its partitioning into throughfall, stemflow and evaporation of intercepted water in four forest ecosystems in western Amazonia. Journal of Hydrology 237, 40-57.

Vaast, P., van Kanten, R.F., Siles, P., Angrand, J., Aguilar, A., 2007. Biophysical interactions between timber trees and Arabica coffee in suboptimal conditions of Central America. In: Jose, S., Gordon, A. (Eds.), Toward Agroforestry Design: An Ecological Approach, Advances in Agroforestry. Springer, pp. 136-148.

van Kanten, R.F., Vaast, P., 2006. Coffee and shade tree transpiration in suboptimal, low-altitude conditions of Costa Rica. Agroforestry Systems 67, 187-202.

Varangis, P., Siegel, P., Giovannuci, D., Lewin, B., 2003. Dealing with coffee crisis in Central America: Impacts and strategies. World Bank Policy Research Working Paper N 2993. The World Bank, Washington DC. 